\title{
Тлеугабулов Д.Т.
}

$\mathrm{PhD}$ докторант, Евразийский национальный университет им. Л.Н. Гумилева, Казахстан, г. Астана, e-mail: danchitto@mail.ru

\section{ИССАЕАОВАНИЕ СРЕАНЕВЕКОВЫХ КУАЬТОВЫХ ПАМЯТНИКОВ АКМОАИНСКОГО ПРИИШИМЬЯ (по материалам разведки 2018 года)}

Аетом 2018 г. разведочным отрядом НИИ археологии им. К.А. Акишева проведены исследования в двух районах Северной Сарыарки: в верховьях Ишима и Тенгиз-Коргалжынском оазисе. Цель Аанного исследования - поиск археологических памятников древности и средневековья в изучаемом районе. Система озер Тенгиз-Коргалжынской впаАины и верховья р. Нура являются привлекательными для расселения как в Аревности, так и в настоящее время. ОАнако, до сих пор Аанная территория остается малоизученной. В работе были применены методы Аистанционного исследования археологических объектов, включающие в себя картографирование с указанием координат памятника в системе глобального позиционирования, описание, фотографирование. В ходе проведения разведки был зафиксирован ряд объектов, ранее не известных для этого региона. Они представляют собой рвы, протянувшиеся от озер на расстояние от 50 до 350 м. Важным и непонятным остается вопрос предназначения этих конструкций. Обнаруженные в ходе разведки памятники были поделены на 3 группы. Также была проведена ревизия ранее исследованных памятников: мавзолеев Жанибек-Шалкар и Батагай. Применение новых методов при их исследовании позволило выявить новые характеристики Аанных объектов. А^я комплексного изучения этих средневековых культовых объектов были проанализированы опубликованные источники.

Ключевые слова: археологическая разведка, средневековье, культовые памятники, ТенгизКоргалжынская впадина, Акмолинское Приишимье, Батагай, Бозок.

\section{Tleugabulov D.T. \\ doctoral candidate, L.N. Gumilyov Eurasian National University, Kazakhstan, Astana, e-mail: danchitto@mail.ru \\ Research of medieval cult monuments of Akmola Upper Ishim (based on 2018 exploration material)}

In the summer of 2018, the reconnaissance detachment of the K.A. Akishev Research Institute of Archeology conducted surveys in two areas of the Northern Saryarka: in the upper Ishim and Tengiz-Korgalzhyn oasis. The purpose of this study is to search for archaeological monuments of antiquity and the Middle Ages in the study area. The system of lakes Tengiz-Korgalzhyn depression and upper Nura river are attractive for settlement, both in antiquity and in the present. However, this territory is still poorly understood. In the work we applied the methods of remote survey of archaeological objects, including mapping with an indication of the coordinates of the monument in the global positioning system, description, photography. During the exploration, we recorded a number of objects previously unknown to this region. They are moats stretching from lakes at a distance of 50 to $350 \mathrm{~m}$. The question of the purpose of these structures remains important and incomprehensible. Discovered during the exploration monuments were divided into 3 groups. We also conducted an audit of previously studied monuments: the Zhanibek-Shalkar and Batagai mausoleums. The use of new methods in their study allowed us to identify new characteristics of these objects. We analyzed published sources for a comprehensive study of these medieval religious objects.

Key words: archaeological exploration, Middle Ages, religious monuments, Tengiz-Korgalzhyn depression, Akmola Upper Ishim, Batagai, Bozok. 


\author{
Тлеугабулов А.Т. \\ $\mathrm{PhD}$ докторанты, А.Н. Гумилев атындағы Еуразия ұлттық университеті, \\ Қазақстан, Астана қ., e-mail: danchitto@mail.ru \\ Ақмола Есік бойының \\ ортағасырлық ғұрыптық ескерткіштерін зерттеу \\ (2018 жылғы барлау жұмыстарының материалдары бойынша)
}

\begin{abstract}
2018 ж. жазда К.А. Ақышев атындағы Археология ҒЗИ барлау отрядымен Солтүстік Сарыарқаның екі ауданында: Есілдің жоғарғы ағысында және Теңіз-Қорғалжын оазисінде барлау жұмыстары жүргізілді. Бұл зерттеудің мақсаты - зерттеліп отырған аудандағы ежелгі және ортағасырлық ескерткіштерді іздеу болды. Теңіз-Қорғалжын ойысы мен Нұра өзенінің жоғарғы ағысының теңіздер жүйесі мекен етуге ежелден де бүгінгі күні қолайлы. Алайда, қазірге дейін бұл аймақ, аз зерттелген. Бұл жұмыста жаһандық жайғастыру жүйесінде ескерткіштің координаттарын көрсете отыра картаға түсіру, зерттеуге тиіс археологиялық нысандарды қашықтықтан зерттеу, сипаттау, фотосуретке түсіру әдістері қолданылды. Барлау жұмыстарын жүргізу барысында бұл күнге дейін белгісіз болған нысандар тіркелді. Олар көлдерден 50-ден 350 метрге дейін қашықтықта созылып жатқан орлар. Бұл құрылыстардың қандай мақсатқа арналғандығы маңызды және түсініксіз болып қалып отыр. Барлау нәтижесінде анықталған ескерткіштер 3 топқа бөлінді. Сонымен қатар бұрын зерттелген ескерткіштерді: Жәнібек-Шалқар және Батағай мавзолейлерін тексеру жүргізілді. Оларды зерттеу кезінде жаңа әдістерді пайдалану бұл нысандардың жаңа қырларын ашуға септігін тигізді. Бұл ортағасырлық ғұрыптық нысандарды кешенді зерттеу үшін жарияланған деректерге талдау жүргізілді.
\end{abstract}

Түйін сөздер: археологиялық барлау, орта ғасыр, ғұрыптық ескерткіштер, Теңіз-Қорғалжын ойысы, Ақмола Есіл бойы, Батағай, Бозоқ.

\section{Введение}

Сарыарка - особый сакральный локус, культурный ландшафт которого сформирован тысячелетней деятельностью предшествующих поколений. Каждая историко-культурная эпоха оставила на этом пространстве свои культовые сакральные центры. Изучение факторов и условий их появления, формирование структуры, связь с определенными периодами и эпохами, причинность и длительность оформления их в особые сакральные ландшафты - основная идея проекта по изучению сакрального ландшафта Сарыарки, в рамках которого проводилась данная работа.

Летом 2018 г. разведочным отрядом НИИ археологии им. К.А. Акишева проведены обследования двух районов Северной Сарыарки: верховий Ишима и Тенгиз-Коргалжынского оазиса. На территории Коргалжынского района Акмолинской области были обследованы берега озер Коргалжын, Султанкельды, Жанибек Шалкар, Кокай, а также побережье р. Нура (рис. 1).

Цель данного исследования - поиск археологических памятников древности и средневековья в изучаемом районе. Одним из ключевых факторов, играющих роль в процессе расселения человеческих коллективов, является наличие водных ресурсов. Тем более важным этот фактор становится в условиях аридной степи. В этом свете, система озер Тенгиз-Коргалжынской впадины и верховья р. Нура являются привлекательными для расселения как в древности, так и в настоящее время. Однако, до сих пор данная территория остается малоизученной.

Археологическая разведка выполняет задачи по поиску, первоначальной фиксации и научной регистрации археологических объектов. Немаловажное значение в ходе археологических разведок уделяется и инспекции ранее обнаруженных памятников с целью своевременного выявления опасности его разрушения. В работе были применены методы дистанционного обследования археологических объектов, включающие в себя картографирование с указанием координат памятника в системе глобального позиционирования, описание, фотографирование. Использование беспилотных летательных аппаратов (БПЛА) при фотографировании позволило выявить новые типы памятников, а также обнаружить ранее не зафиксированные особенности у уже исследованных объектов. 


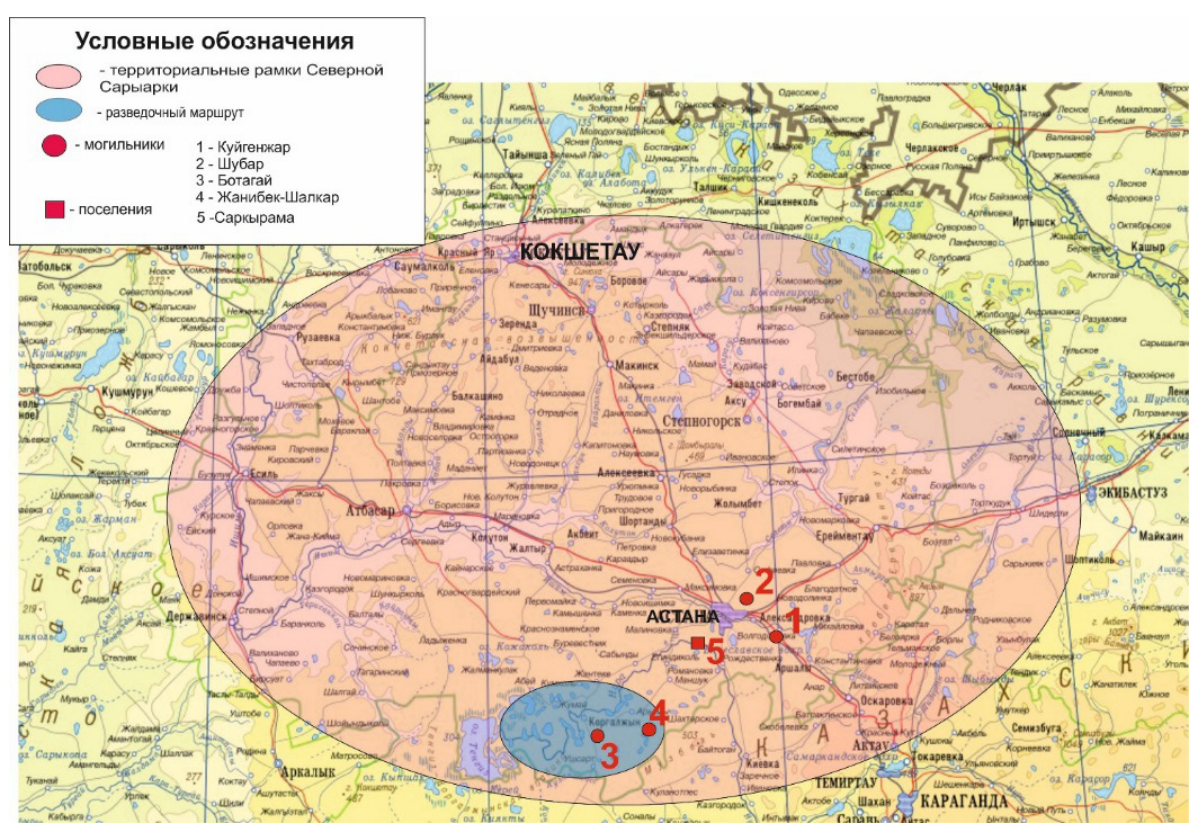

Рисунок 1 - Район разведочного обследования и культовые объекты Акмолинского Приишимья

\section{Методы исследования}

Описание разведочных работ в полевом сезоне 2018 года

В ходе проведения разведки был зафиксирован ряд объектов, ранее не известных для этого региона. Они представляют собой рвы, протянувшиеся от озер на расстояние от 50 до 350 м. Расстояние между такими рвами варьируется от нескольких десятков до нескольких сот метров. Какой-либо связной системы их расположения не выявлено. Рвы к настоящему времени заплыли, дно их покрыто гидрофильной растительностью. Глубина на данный момент не превышает 1 м (рис. 2). Важным и непонятным остается вопрос предназначения этих конструкций. Очевидно, что они не были предназначены для орошения возделываемых культур, т.к. почвы в данной местности заболоченные и солончаковые. Неубедительным представляется и довод в пользу использования этих арыков для водопоя скота. Скот имеет свободный доступ к воде вдоль берегов водоемов. Наиболее вероятным выглядит предположение, что эти канавы использовались в качестве ловушек при загонном способе охоты, высказанное ранее исследователем фауны и сотрудником заповедника А.В. Кошкиным (Кошкин, 2011: 37). Данное предположение предстоит проверить, изучив способы загонной охоты казахов на крупную копытную дичь, в том числе и с привлечением материалов по этнографии казахского народа. Для этого потребуется привлечь больше полевого материала, изучить архивные сведения на предмет упоминания подобных конструкций для других регионов, а также рассмотреть материалы по этнографии казахского народа, связанные с ритуалами и действиями во время проведения охоты - важного занятия казахов, имитирующего боевые действия.

Помимо этого, был заново проинспектирован мавзолей Жанибек Шалкар, расположенный на высоком коренном берегу озера ЖанибекШалкар, в 26 км восточнее поселка Коргалжын. Объект фиксировался на поверхности распашки покрытой бурьяном, как небольшое всхолмление, поверхность которого покрыта значительным количеством фрагментов жженого кирпича, а также осколков глазурованной плитки со штампованным орнаментом. Данный объект был исследован отрядом НИИ археологии им. К.А. Акишева в 2009-2010 гг. (Хабдулина и др., 2011). Археолого-архитектурные параллели, топонимика края и редкий по красоте полихромный декор позволили отнести мавзолей к типу элитных мемориалов XIV-XV вв. и идентифицировать его как мавзолей Жанибексултана - основателя Казахского ханства (Хабдулина, Табулдин, 2015: 102). Для уточнения данного предположения необходимо продолжить исследование данного объекта. В первую очередь, это связано с проведением полномасштабных полевых исследований, завершени- 
ем археологического изучения мавзолея. Для идентификации погребенных в мавзолее необходимо привлечение методов палеогенетики и физической антропологии с целью реконструкции облика усопших. Эти задачи нами ставятся на следующие годы.

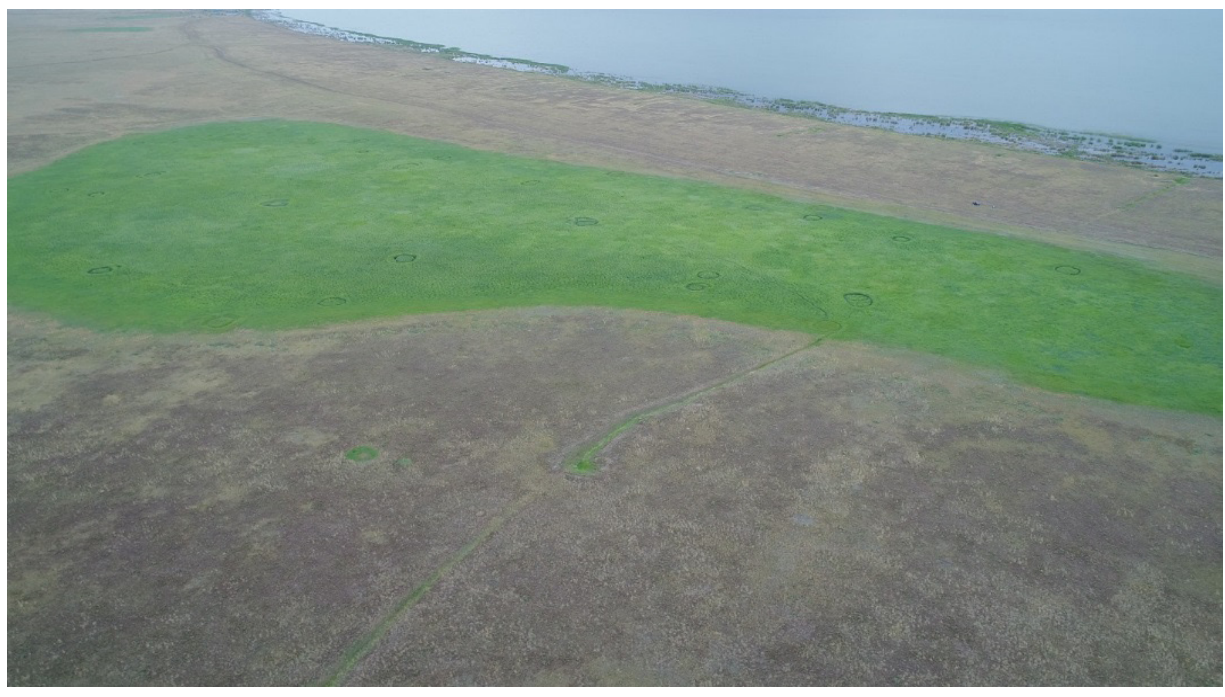

Рисунок 2 - Ров, протянувшийся от озера Султанкельды

Обнаруженные в ходе разведки памятники можно поделить на 3 группы. В первую группу мы относим курганы и курганные могильники. Не исключено, что исследованные одиночные курганы ранее являлись частью курганных могильников. Особенностью рельефа изучаемого района являются пологие холмы, удобные для распашки. Как следствие практически все господствующие возвышенности в районе исследования долгое время подвергались сельскохозяйственной обработке. Сохранились, как правило, курганы, на которых установлены геодезические знаки, охраняемые государством, либо находящиеся на территории кладбища.

Вторая группа памятников - мавзолеи нового времени. Традиция возведения мавзолеев в казахстанских степях берет начало с эпохи Золотой Орды, времени окончательного становления ислама в регионе. Таким образом, возраст данных практик составляет около 700 лет (Khabdulina et al., 2015). В силу множества объективных факторов, как природных, так и антропогенных, подавляющее большинство средневековых памятников подобного рода до нас в целости не дошло. Однако, мы имеем возможность изучать традиции и приемы строительства, проводить культурные аналогии благодаря исследованию казахских мавзолеев нового времени (Хабдулина и др., 2018: 162). Еще одной немаловажной причиной изучения этих памятников является их сравнительная недолговечность. Как правило, основной материал для постройки мавзолеев кирпич-сырец, очень легко разрушающийся под воздействием внешних факторов.

К третьей группе относятся зимовки-кыстау, датирующиеся XIX - началом XX веков. Указанная выше датировка базируется на найденных артефактах (осколки керамики), а также на культурных аналогиях (Дукомбайев, 2011: 465). Как показала разведка, большинство найденных памятников такого рода находится у берегов рек, на мысах, образованных естественными изгибами реки Нуры, либо, если речь идет об озере, то на приподнятых площадках выше уровня поймы. Как правило, большинство зимовок-кыстау появляется в регионе в XIX веке, что связано с начавшимся процессом седентаризации (Бейсенов, 2002: 34).

Также в ходе исследования в данном регионе нами был осмотрен мавзолей Батагай и прилегающий к нему Некрополь. Мавзолей Батагай - один из наиболее известных погребальных памятников средневекового периода степной Сарыарки. Расположен он в низовьях реки Нуры, в 2 км к востоку от поселка Коргалжын, в 1 км от русла реки. Впервые был описан Рычковым П.И. в 1762 г. в его знаменитом труде, посвященном Оренбургскому краю (Рычков, 1762: 259-263). 
Однако, в Центральном Казахстане П. Рычков не был. Поэтому памятники этого района были описаны им по материалам экспедиции, рассказам путешественников и русских людей, побывавших в казахских степях. Тем не менее, его труд до сих пор не потерял своей научной ценности.

Одним из самых известных описаний Батагая является заметка инженера И.П. Шангина, опубликованная в 1820 г. (Шангин, 1820). Он описал большое количество архитектурных сооружений в долине реки Нуры. В частности, про мавзолей Батагай он пишет: «Оно построено из кирпича; внутри его находятся столбы, покрытые алебастровой штукатуркой, равно как и стены, имеющие вместо связей четвероугольные сосновые брусья в два вершка в поперечнике, для большей прочности, обожженные и покрытые камышом» (Шангин, 1820).

Мавзолей был принят И. Шангиным за развалины городского храма, а окрестный некрополь - за руины древнего города. Эта заметка вызвала волну интереса у исследователей, пытавшихся найти этот загадочный город. С этой целью работы в этом месте проводила Центрально-Казахстанская археологическая экспедиция под руководством А.Х. Маргулана в 1947 и 1949 гг. XX века. Никаких свидетельств существования древнего города, за исключением небольших поселений и обширных гробниц, обнаружено не было (Маргулан и др., 1966: 29).
Но тем не менее А.Х. Маргулан локализует на месте городища Батагай таинственный город Aqcxint - Акша-Кент, отмеченный на средневековых итальянских картах, в частности, на карте Пицигани, а также на Каталонской карте. На последней этот город показан как торговый центр на караванных путях из Сарайчика в Алмалык через Тургайские и Сарысуйские степи (Маргулан и др., 1966: 10).

В результате проведенных нами исследований на месте развалин средневекового мавзолея также никаких признаков оседлого поселения не обнаружено. Мавзолей Батагай расположен в центре обширного некрополя, который на данный момент представляет из себя едва различимые на поверхности земли всхолмления. Представляется вполне очевидным, что русские ученые-путешественники, в том числе И.П. Шангин, не знакомые со спецификой возведения подобных надмогильных сооружений, принимали их развалины за руины стен городов.

Комплексное обследование местности, в том числе с применением квадрокоптера, позволило нам заключить, что остатки древнего города в окрестностях мавзолея не фиксируются. Использование фотографий, сделанных с высоты птичьего полета, позволило нам более детально рассмотреть и выделить наземные конструкции некрополя (рис. 3).

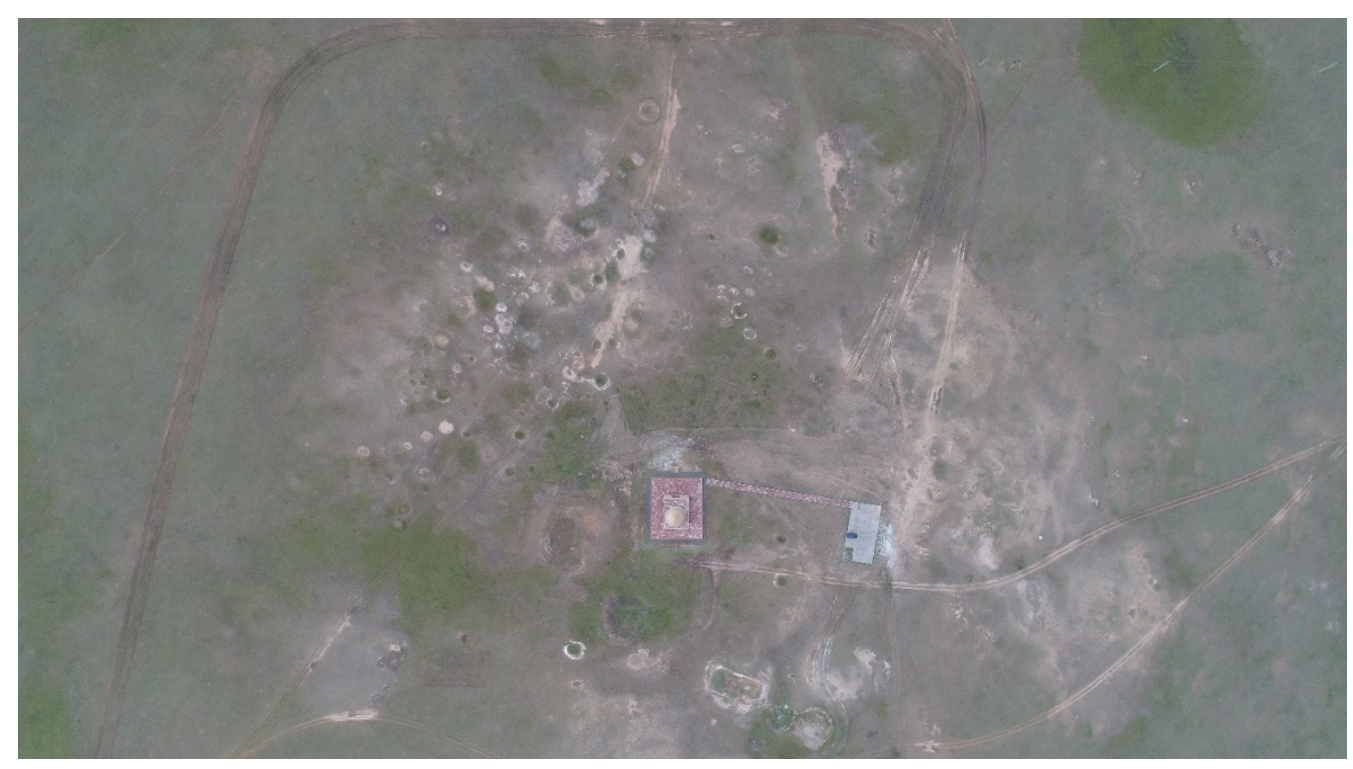

Рисунок 3 - Некрополь Батагай 
В первую очередь, следует отметить наличие развалов двух крупных сооружений. Одно из них - непосредственно сам мавзолей Батагай, исследованный специалистами «Казреставрации» в 2007 году (Семби, 2015: 149). В 100 м юго-западнее от него расположены развалины еще одного крупного сооружения, круглого в плане, диаметром около 7 м. Вероятно, это развалины второго храма, упоминаемого И.П. Шангиным: «Близ его храма приметны следы другого подобного, а далее в восточную и западную стороны находится множество развалившихся зданий, из коих некоторых основание составляет до 300 сажень в длину, и в совокупности издали представляются они известковыми горами» (Шангин, 1820).

В 10 м к северу от мавзолея находятся остатки кирпичеобжигательной печи, также подвергнутой раскопкам. В непосредственной близости от нее расположены две ямы, выбранный грунт из которых, вероятно, использовался в качестве сырья для производства кирпичей.

Обломки кирпичей разного размера и разной степени сохранности в большом количестве встречаются в подъемном материале на территории вокруг мавзолея. По обнаруженным находкам выявились размеры кирпичей, использованные при строительстве памятника: $22 \times 11 \times 4,5$ см; $22 \times 11 \times 4$ см; $35 \times 22 \times 5$ см, а также квадратные $22 \times 22 \times 5$ см. Все кирпичи хорошего обжига. Встречаются фрагменты поливной терракоты. Она, вероятнее всего, украшала портальную часть мавзолея.

Результаты раскопок мавзолея, проведенные в 2007 г., сотрудниками Института культуры и искусствознания (М.К. Семби, Ж.А. Шайкеном), дали неожиданный результат - захоронения в нем не производились (Семби, 2015: 154).

Четко обозначить все погребения данного некрополя довольно сложно. Как уже было отмечено, все они представляют из себя небольшие, до 4 м в диаметре, округлые или овальные земляные оградки, едва различимые на поверхности земли. При осмотре могильника с высоты можно определить его примерные масштабы: погребения локализуются на площадке размерами около 100x100 м к юго-западу от его развалин, то есть напротив портальной части стоявшего некогда мавзолея. Нами выделены не менее 76 оградок разного размера в этой части некрополя.

Определить наличие погребений с северной и западной сторон от развалин мавзолея невозможно в силу проведения там строительных работ, связанных с реконструкцией мавзолея, представляющей собой, по сути, возведение полностью нового сооружения, т.н. «новострой» (рис. 4).

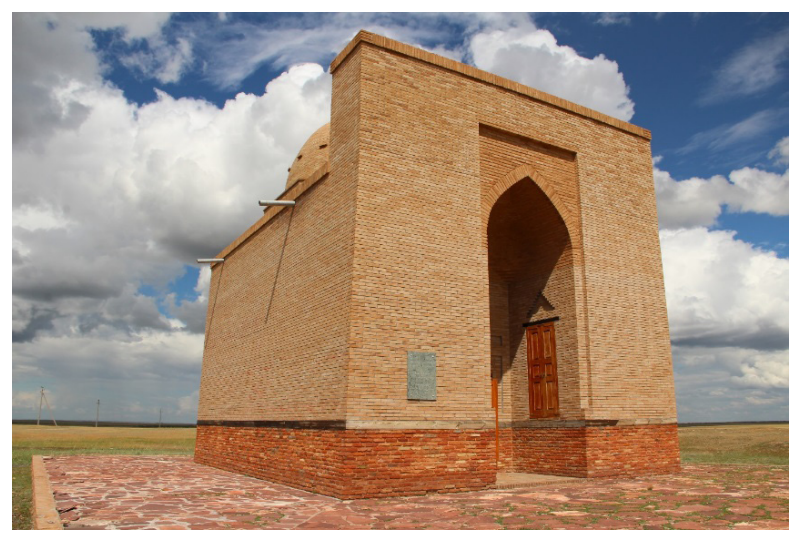

Рисунок 4 - Реконструкция мавзолея Батагай

Еще одним интересным объектом некрополя является сооружение, расположенное в 120 м к северо-востоку от мавзолея. Этот объект представляет собой круглую в плане оградку диаметром 8 м. Стены оградки выполнены из сырца, развалы стен мощные, шириной 2,5-3 м. С восточной стороны оставлена перемычка шириной около $1 \mathrm{M}$.

В 2012 году специалистами РГП «Казреставрация〉 была выполнена реконструкция мавзолея. Как уже было отмечено, воссозданный объект представляет собой совершенно новый мавзолей, построенный поблизости от развалин археологического объекта. Это портальнокупольный мавзолей с нишами по сторонам от входа, углубленного внутрь помещения. Говорить об исторической достоверности данной реконструкции сложно, так как не сохранились изображения мавзолея до его разрушения.

Наиболее ценным материалом для реконструкции представляются чертежи из архива Ш. Уалиханова и «рисунок» А. Шахматова, выполненные в 1831 г. при осуществлении в военно-стратегического задания - «описать древние развалины города Татагая». Задание это было выполнено, и сотник А. Шахматов представил начальству «рисунок древнего здания Татагая с особым описанием». Признаков же древнего города он не обнаружил. Рисунок этот дошел до наших дней (Сембин, 1975: 7).

Комментарий к нему оставлен в работе подполковника Красовского «Область сибирских киргизов», изданной в 1868 году. «По его описанию могила Ботагая сохранилась почти в цело- 
сти. Длина основания кирпичного корпуса могилы 5 саж., ширина 4 саж; вышина 3, до стоящего над корпусом купола 2, всего 5 сажень, внутри корпус имеет тоже прямоугольное основание; по стенам могилы 3 большие ниши, и над каждою три малые; стены внутри выштукатурены и выбелены. В основании купола 4 отдушины, каждая высотою в 1 аршин, шириною 3.4 арш. В основании могилы заметна кладка в два ряда брусьев, добытых вероятно из ближайших ущелий. Кирпич имеет форму квадрата в 6 вершков по стороне; толщина его вершок. Сведения эти и план могилы Ботагая можно найти в тех топографических описаниях степной местности, составленных офицерами сибирского казачьего войска, которые в числе 7 тетрадей, хранятся в архиве генерального штаба под номером 33363» (Красовский, 1868: 254).

Большой интерес представляют статьи Ш.Ш. Уалиханова о киргиз-кайсацких «молах». «В кайсацкой моле и около нее выражается весь вкус кайсака, его искусство в архитектуре, его резьба и живопись», пишет Уалиханов. Он дает высокую оценку архитектурному искусству казахского народа. Помимо собственных исследований Ш.Ш. Уалиханова, в 3 том вошел его архив, в котором можно найти весьма ценные и редкие материалы по истории народов Средней Азии и Казахстана. План и разрез мавзолея Бутагая из архива Ш. Уалиханова являются графическим материалом.

Описывая Кенгирские мавзолеи, ученый говорит: «Эти могилы такая редкость, какая во всей степи уже не повторяется, кроме Нуры, недалеко от устья которой лежит могила Батагай; о ее устройстве я ничего положительного не имею». По-видимому, ученый не успел осмотреть этот замечательный памятник (Маргулан, 1967: 202).

Эти чертежи дают общее представление о типе купольного мавзолея. Возможно, имелся развитый портал, о чем говорит наличие боковых камер со стороны главного фасада. По чертежу Шахматова ясно видно наличие четверика, выполненного для перехода к восьмерику. Купол опирался на восьмигранный барабан, угловые грани которого перекидывались через углы квадратного помещения арками, образуя собой так называемые арочные паруса. Три ниши в помещении, зафиксированные в чертежах и отмеченные многими исследователями, позволяют сравнивать этот памятник с мавзолеем Алашахана. Эпиграфический орнамент, завоевавший в декоре зданий значительное место в мавзолеях
Средней Азии уже в $\mathrm{X}$ веке, получает дальнейшее развитие и в степях Казахстана (Baitenov et. al., 2019: 92). А. Шахматов, не знавший восточных языков, постарался срисовать эпиграфику мавзолея Батагай, но, к великому сожалению, с этой задачей не справился и надпись до сих пор является загадкой (Семби, 2015: 12).

Далее исследователь делает выводы об итогах изучения мавзолея. Мавзолей Батагай ориентирован главным фасадом на юго-запад. Как и на многих средневековых мавзолеях здесь отсутствует фундамент. Его отсутствие заменялось тщательным подбором холма, на котором строился мазар. Почва должна была содержать в основном устойчивые породы и легко пропускать влагу.

Толщину стен очень трудно определить, поскольку внутренняя часть остатков стен сооружения сильно разрушена, но все же по остаткам можно предположить, что толщина ее составляет около 80-90 см. Мавзолей сильно разрушен, что затрудняет по результатам археологических раскопок решить вопрос о планировке его в целом, выяснить применение разнообразных строительных конструкций, материалов и др. (Семби, 2015: 21).

\section{Заключение}

В результате разведочного обследования выделены крупные территориальные образования, насыщенные культовыми объектами разных эпох. Комплексное исследование этих территорий с ландшафтных и историко-культурных позиций позволяет трактовать их как особые сакральные территории - духовные центры генетической связи поколений. Наиболее ярким локальным регионом является территория Тенгиз-Коргалжынской впадины. По результатам наших исследований нами выделено несколько центров. Одним из них является нижнее течение реки Нуры и система Тенгиз-Коргалжынских озер. В ходе разведочного обследования этой местности был зафиксирован ряд объектов, ранее не известных для этого региона. Важным и непонятным остается вопрос предназначения этих конструкций. Его предстоит решить нам в ходе дальнейших исследований.

Еще один локальный регион сакральной территории представлен Бозокским археологическим микрорайоном, расположенным на территории столицы Казахстана - г. Нур-Султан.

Мавзолей Батагай - это один из наиболее известных погребальных памятников средневе- 
кового периода степной Сарыарки. Известность этому объекту принесло ошибочное упоминание в русских источниках большого города в этой местности. Наши исследования в очередной раз подтвердили недостоверность этих сведений. Кроме того, нами впервые была предпринята попытка описания существующего некрополя у мавзолея Ботагай. Нами были выделены не менее 76 погребальных конструкций. Все они очень плохо фиксируются на поверхности земли при визуальном осмотре. Использование беспилотного летательного аппарата позволило нам добиться более существенных результатов.
Несомненно, что мавзолей Батагай является одним из важных сакральных центров Северной Сарыарки. Формирование возле него обширного некрополя подтверждает это. Мы считаем, что этот памятник может стать важным туристическим объектом, расположенным в очень выгодном месте - рядом с всемирно известным заповедником Коргалжын. Наши дальнейшие исследования данного объекта должны способствовать возрастанию популярности мавзолея у туристов и становлению его как самостоятельного и самодостаточного туристического центра.

\section{Литература}

Бейсенов А.3. (2002) Исследования Сарыаркинской экспедиции в Центральном Казахстане . Известия МОН РК. Серия общественных наук. Алматы. № 1. С. 31-41.

Дукомбайев А.Т. (2013) К вопросу о типологии казахских зимовок . Актуальные вопросы истории развития Казахстана и становления казахстанской государственности. Астана. С. 465-469.

Кошкин А.В. (2011) О чем молчит степь . Степной бюллетень. № 33. С. 36-37.

Красовский Н.И. (1868) Область Сибирских киргизов. Материалы для географии и статистики России, собранные офицерами Генерального штаба. Санкт-Петербург. Ч. 2.- 464 с.

Маргулан А.Х. (1967) Чокан Чингисович Валиханов. Собр. соч. в пяти томах. Т.3. Алматы. 783с.; с илл.

Маргулан А.Х., Акишев К.А., Кадырбаев М.К., Оразбаев А.М. (1966) Древняя культура Центрального Казахстана. Алматы. 437 с.

Рычков П.И. (1762) Топография Оренбургская. Ч. ІІ. Санкт-Петербург. С.259-263.

Семби М.К. (2015) Мавзолей Ботагай - памятник средневековой казахской архитектуры (краткая история исследования) . Национально-освободительная борьба казахского народа. Булантинская битва. Астана. С. 149-154.

Сембин М.К. (1975) Мавзолеи Ботагай, Сырлы-Там, Сулу-Там (историко-археологические материалы). Отчет проектносметного отдела Научно-реставрационного отдела Министерства культуры КазССР. Алматы. 80 с.

Хабдулина М.К., Бонора Ж.Л., Билялова Г.Д. (2018) Сакральная карта Акмолы: новые материалы . Интеграция археологических и этнографических исследований: материалы XXII международного научного симпозиума. ОмскПавлодар. С. 162-165.

Хабдулина М.К., Кожамжаров К.Т., Ярыгин С.А., Калдыбаев М.С., Сакенов С.К., Свиридов А.Н. (2011) Культовые памятники Тенгиз-Коргалжинской впадины. Астана: ЕНУ им. Л.Н. Гумилева. - 208 с., илл. (каз., рус.яз.)

Хабдулина М.К., Табулдин Г. (2015) Мавзолей Жанибек Шалкар. Археологическое исследование памятника . Мәдени мұра. - № 1 (58). С. 96-103.

Шангин И. П. (1820) Извлечение из описания экспедиции, бывшей в Киргизскую степь в 1816 года . Сибирский вестник. Ч. 11.

Baitenov, E., Tuyakayeva, A., \& Abdrassilova, G. (2019). Medieval mausoleums of kazakhstan: Genesis, architectural features, major centres. Frontiers of Architectural Research, 8(1), 80-93. doi:10.1016.j.foar.2018.11.001

Khabdulina M.K., Orazbaeva Z.B., Tleugabulov D.T. (2015) The Spread of Islam in Dasht-I Kipchak . The IX International Academic Congress «Contemporary Science and Education in Americas, Africa and Eurasia», Rio de Janeiro, Brazil, 18-20 August 2015 .

\section{References}

Beysenov A.Z. (2002) Issledovaniya Saryiarkinskoy ekspeditsii v Tsentralnom Kazahstane [Research of the Saryarka expedition in Central Kazakhstan] . Izvestiya MON RK. Seriya obschestvennyih nauk. Almaty. №1. pp. 31-41.

Dukombayev A.T. (2011) K voprosu o tipologii kazahskih zimovok [On the typology of Kazakh wintering] . Aktualnyie voprosyi istorii razvitiya Kazahstana i stanovleniya kazahstanskoy gosudarstvennosti. Astana. pp. 465-469.

Koshkin A.V. (2011) O chem molchit step [What the steppe is silent about] . Stepnoy byulleten. № 33. S. 36-37.

Krasovskiy N.I. (1868) Oblast Sibirskih kirgizov. Materialyi dlya geografii i statistiki Rossii, sobrannyie ofitserami Generalnogo shtaba [The Region of Siberian Kyrgyz. Materials for geography and statistics of Russia, collected by officers of the General Staff]. Sankt-Petersburg. Ch. 2. 464 p.

Margulan A.H. (1967) Chokan Chingisovich Valihanov. Sobr. soch. v pyati tomah [Chokan Chingisovich Valikhanov. Collected works in five volumes]. T.3. Alma-Ata. 783 p.; ill. 
Margulan A.H., Akishev K.A., Kadyirbaev M.K., Orazbaev A.M. (1966) Drevnyaya kultura Tsentralnogo Kazahstana [Ancient culture of Central Kazakhstan]. Alma-Ata. 437 p.

Ryichkov P.I. (1762) Topografiya Orenburgskaya [Topography of Orenburg]. Ch. II. Sankt-Petersburg. pp. 259-263.

Sembi M.K. (2015) Mavzoley Botagay - pamyatnik srednevekovoy kazahskoy arhitekturyi (kratkaya istoriya issledovaniya) [Botagai Mausoleum is a monument of medieval Kazakh architecture (a brief history of the study)] . Natsionalno-osvoboditelnaya borba kazahskogo naroda. Bulantinskaya bitva. Astana. pp. 149-154.

Sembin M.K. (1975) Mavzolei Botagay, Syirlyi-Tam, Sulu-Tam (istoriko-arheologicheskie materialyi). Otchet proektno-smetnogo otdela Nauchno-restavratsionnogo otdela Ministerstva kulturyi KazSSR. [Mausoleums Botagay, Syrly-Tam and Sulu-Tam (historical and archaeological materials). Report of the design and budget department of the Scientific and Restoration Department of the Ministry of Culture of the Kazakh SSR] Alma-Ata. $80 \mathrm{p}$.

Habdulina M.K., Bonora Zh.L., Bilyalova G.D. (2018) Sakralnaya karta Akmolyi: novyie materialyi [Sacred map of Akmola: new materials] . Integratsiya arheologicheskih i etnograficheskih issledovaniy: materialyi XXII mezhdunarodnogo nauchnogo simpoziuma. - Omsk-Pavlodar. pp. 162-165.

Habdulina M.K., Kozhamzharov K.T., Yaryigin S.A., Kaldyibaev M.S., Sakenov S.K., Sviridov A.N. (2011) Kultovyie pamyatniki Tengiz-Korgalzhinskoy vpadinyi [Religious monuments of the Tengiz-Korgalzhinskoy depression]. Astana: ENU im. L.N. Gumileva. 208 p., ill. (kaz., rus.yaz.)

Habdulina M.K., Tabuldin G. (2015) Mavzoley Zhanibek Shalkar. Arheologicheskoe issledovanie pamyatnika [Mausoleum of Zhanibek Shalkar. Archaeological research of the monument] . Madeni mura. №1 (58). pp. 96-103.

Shangin I.P. (1820) Izvlechenie iz opisaniya ekspeditsii, byivshey v Kirgizskuyu step v 1816 godu [Extract from the description of the expedition that was in the Kyrgyz steppe in 1816] . Sibirskiy vestnik. Ch. 11.

Baitenov, E., Tuyakayeva, A., \& Abdrassilova, G. (2019). Medieval mausoleums of kazakhstan: Genesis, architectural features, major centres. Frontiers of Architectural Research, 8(1), 80-93. doi:10.1016.j.foar.2018.11.001

Khabdulina M.K., Orazbaeva Z.B., Tleugabulov D.T. (2015) The Spread of Islam in Dasht-I Kipchak . The IX International Academic Congress «Contemporary Science and Education in Americas, Africa and Eurasia», Rio de Janeiro, Brazil, 18-20 August 2015 . 